DOE/NE/44139-75

Distribution Category UC-510

\title{
RADIATION SAFETY AT THE \\ WEST VALLEY DEMONSTRATION PROJECT
}

\author{
Topical Report
}

By

Robert L. Hoffman

May 6, 1997

Work Performed Under Contract No. DE-AC24-81NE44139

Prepared for

U.S. Department of Energy

Assistant Secretary for Environmental Management

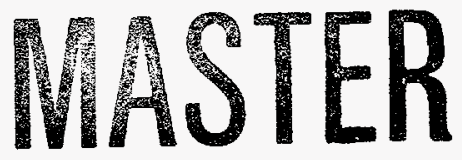

Prepared by

West Valley Nuclear Services Company, Inc.

West Valley, NY 14171

DISTRIBUTION OF THIS DOCUMENT IS UNLIMTTED 



\section{DISCLAIMIER}

Portions of this document may be illegible in electronic image products. Images are produced from the best available original document. 



\section{TABLE OF CONTENTS}

$\underline{\text { Section }}$

Page

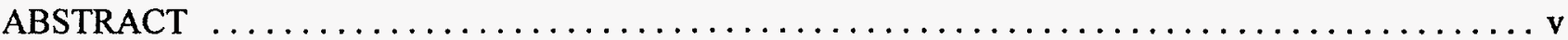

ACKNOWLEDGEMENTS $\ldots \ldots \ldots \ldots \ldots \ldots \ldots \ldots \ldots \ldots \ldots \ldots \ldots \ldots \ldots \ldots \ldots \ldots \ldots$

EXECUTIVE SUMMARY $\ldots \ldots \ldots \ldots \ldots \ldots \ldots \ldots \ldots \ldots \ldots \ldots \ldots \ldots \ldots \ldots \ldots \ldots \ldots \ldots \ldots$

1.0 Assuring That Occupational Radiation Exposures are As Low as Reasonably Achievable ........ 1 (ALARA)

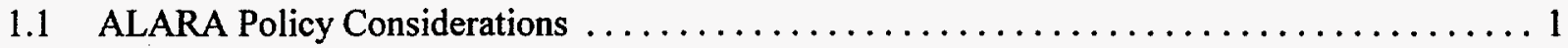

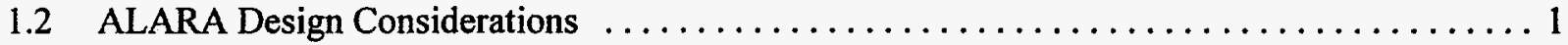

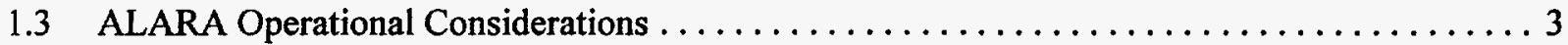

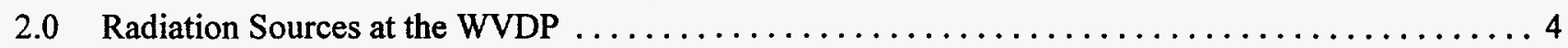

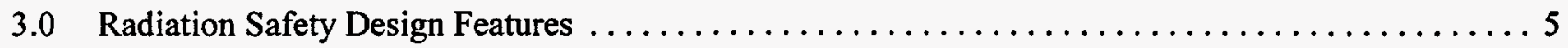

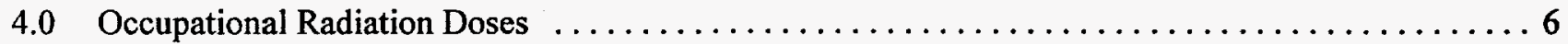

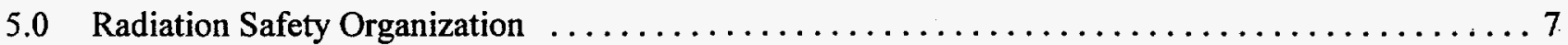

5.1 Vice President for Environmental, Safety, Health, and Quality Assurance $\ldots \ldots \ldots \ldots \ldots 7$

5.2 Radiation Protection Manager . . . . . . . . . . . . . . . . . . . . . . . . 7

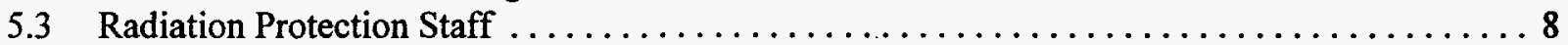

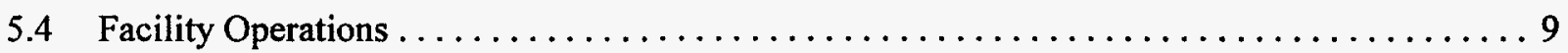

5.5 Radiation and Safety Committee $\ldots \ldots \ldots \ldots \ldots \ldots \ldots \ldots \ldots \ldots \ldots \ldots \ldots$

6.0 Radiation Detection Equipment, Instrumentation, and Support Facilities $\ldots \ldots \ldots \ldots \ldots \ldots$

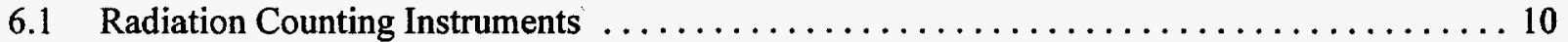

6.2 Portable Radiation Detection Instruments $\ldots \ldots \ldots \ldots \ldots \ldots \ldots \ldots \ldots \ldots \ldots \ldots \ldots \ldots \ldots \ldots$

6.3 Airborne Contamination Sampling and Monitoring Equipment $\ldots \ldots \ldots \ldots \ldots \ldots \ldots \ldots 12$

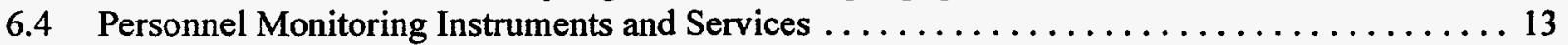

6.5 Instrument Storage, Calibration, and Maintenance Facilities $\ldots \ldots \ldots \ldots \ldots \ldots \ldots \ldots \ldots 14$

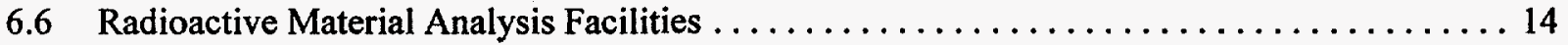

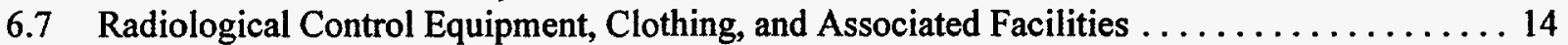

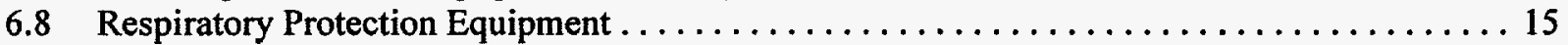

6.9 Equipment and Personnel Decontamination Facilities $\ldots \ldots \ldots \ldots \ldots \ldots \ldots \ldots \ldots$

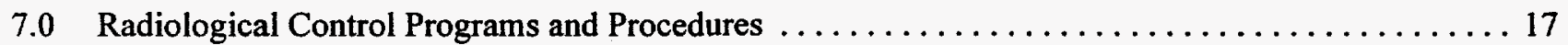

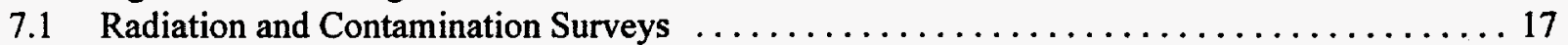

7.2 Procedures for Ensuring that Occupational Doses are ALARA $\ldots \ldots \ldots \ldots \ldots \ldots \ldots \ldots$

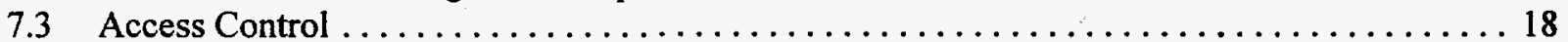

7.4 Sealed Radioactive Sources and Radioisotope Control . . . . . . . . . . . . . . . . . 22

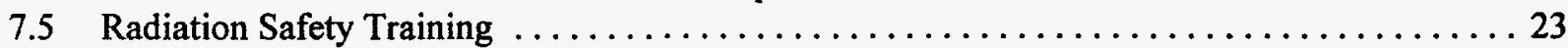




\section{TABLE OF CONTENTS (cont.)}

Section

7.0 Radiological Control Programs and Procedures (cont.)

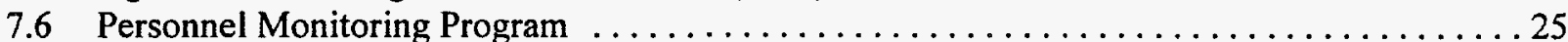

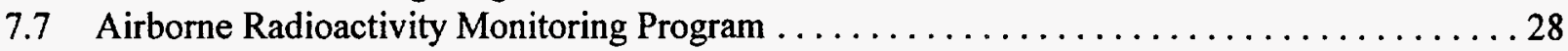

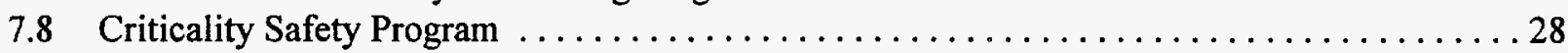

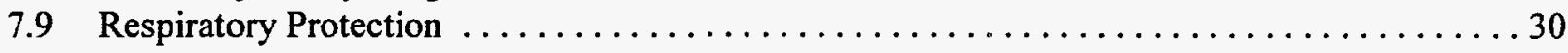

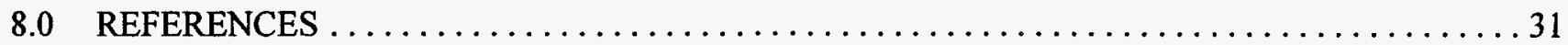

Figure

Figure

$\underline{\text { Page }}$

4-1 Occupational Radiation Dose Received by Workers at the WVDP .6 


\begin{abstract}
This is a report on the Radiation Safety Program at the West Valley Demonstration Project (WVDP). This Program covers a number of activities that support high-level waste solidification, stabilization of facilities, and decontamination and decommissioning activities at the Project. The conduct of the Program provides confidence that all occupational radiation exposures received during operational tasks at the Project are within limits, standards, and program requirements, and are as low as reasonably achievable.
\end{abstract}




\section{ACKNOWLEDGMENTS}

The successful execution of the activities described in this report requires the support of a number of on-site organizations, as well as a dedicated staff of radiation safety professionals, and technical and administrative support personnel. The high standards established by the Radiation Safety Program at the WVDP requires many on-site organizations; including Operations, Maintenance, Engineering, and Project Administration as well as other environmental, safety, health, and quality assurance groups and a number of subcontractors and suppliers; working together to create a safer environment to perform their jobs. The author would like to thank all these individuals for their skill and dedication in establishing and maintaining a comprehensive and effective Radiation Safety Program. 


\section{EXECUTIVE SUMMARY}

The mission of the West Valley Demonstration Project is set forth in Public Law 96-368, "West Valley Demonstration Project Act," (WVDPA) which authorizes the U.S. Department of Energy (DOE) to carry out a high-level liquid nuclear waste management demonstration project at the Western New York Nuclear Service Center (WNYNSC) in West Valley, NY, to prepare high-level radioactive waste for disposal. To accomplish this activity: the high-level radioactive waste at the WNYNSC is to be solidified by vitrification or by other technology determined to be the most effective, containers suitable for permanent disposal of the high-level waste are to be developed, the solidified waste is to be transported to an appropriate federal repository for permanent disposal, the low-level radioactive waste and transuranic waste is to be disposed of, and the tanks, facilities, materials, and hardware, in which the high-level solidified radioactive waste was stored or used in the solidification process, are to be decontaminated and decommissioned.

In February 1982, West Valley Nuclear Services Company, Incorporated (WVNS), a subsidiary of Westinghouse Electric Corporation, assumed management and operational control of the site as the prime contractor for the DOE. The WVDP consists of those facilities and the high-level radioactive waste portion of the WNYNSC that New York State has agreed with the DOE, under the WVDPA, as being necessary for completion of the Project. The Facility consists primarily of the former commercial nuclear fuel reprocessing center and a 200-acre exclusion area. The radiation safety hazards with the high-level, transuranic, and lowlevel radioactive wastes involve both direct external and internal radiation exposures during waste processing and handling, decontamination and decommissioning, and vitrification activities as discussed under the mission of the WVDP.

The DOE, along with WVNS, are dedicated to ensuring that the conduct of radiological operations protects the health and safety of all its employees, contractors, and the general public. In achieving this objective, the DOE and WVNS provide confidence that radiation exposures to its workers and the public, and releases of radioactivity to the environment are maintained below regulatory limits and, in addition, deliberate efforts are taken to further reduce exposures and releases in accordance with a process that seeks to make any such exposures or releases as low as reasonably achievable (ALARA). The DOE and WVNS are fully committed to implementing a Radiation Safety Program of the highest quality that reflects this policy.

This report provides details on the equipment, methods, and procedures used in carrying out the Radiation Safety Program at the WVDP. 



\subsection{ASSURING THAT OCCUPATIONAL RADIATION EXPOSURES ARE AS LOW AS REASONABLY ACHIEVABLE (ALARA)}

\subsection{ALARA Policy Considerations}

A formally documented program directed toward maintaining personnel radiation doses as low as reasonably achievable (ALARA) is in place for the WVDP. Requirements were originally set forth in DOE Order 5480.1, Chapter XI, "Requirements for Radiation Protection," with recommended guidance contained in the DOE publication, DOE/EV/1830-T5, "A Guide to Reducing Radiation Exposures to As Low As Reasonable Achievable (ALARA)." In December 1988, these DOE requirements were superseded by DOE Order 5480.11, "Radiation Protection for Occupational Workers," with recommended guidance contained in the DOE publication, DOE/PNL-6577, "Health Physics Manual of Good Practices to Reducing Radiation Exposure to Levels that are As Low As Reasonably Achievable (ALARA)." In June 1992, the DOE issued additional ALARA requirements in DOE/EH-0256T, "DOE Radiological Control Manual." In December 1993, the DOE established federal codified requirements based on those appearing in DOE Order 5480.11 in Title 10, Code of Federal Regulations, Part 835, "Occupational Radiation Protection," along with guidance provided in DOE Implementation Guide G-10 CFR 835/B2, "Occupational ALARA Program."

This Program is required by management policy as set forth in WVNS Policy and Procedure WV-984, "ALARA Program," which is coordinated by the Vice President for Environmental, Safety, Health, and Quality Assurance, and implemented by line management. The implementing programmatic document for both the occupational and environmental aspects of the ALARA Program is WVNS Project Document WVDP-163, "WVDP ALARA Program Plan." In essence, the ALARA Program establishes annual radiological performance goals, work conduct and design requirements, and ALARA training, etc., that assist in meeting the preset goals and ALARA process requirements. The annual radiological performance goals include dose, contamination, and waste reduction objectives. Progress toward meeting the performance goals is reported to management quarterly, with an annual summary report presenting the accomplishments from the previous year and established goals and corresponding activities for the following year.

\subsection{ALARA Design Considerations}

The design requirements contained in DOE requirements have been implemented at the WVDP. Periodic design reviews are conducted with ALARA principles incorporated into design documents, i.e., design bases and drawings, where applicable. The requirements for ALARA design reviews have been provided in WVDP-163 where programmatic objectives as well as details for consideration are described.

\subsubsection{General Design Considerations for Maintaining Exposures ALARA}

General design considerations and methods employed to maintain radiation doses ALARA, as required by WVDP-163, are as follows:

- Measures are taken to maintain radiation exposure in controlled areas as low as reasonably achievable through Facility and equipment design and administrative controls. The primary methods used are physical design features (e.g., confinement, ventilation, remote handling, and shielding).

Administrative controls and procedural requirements are employed only as supplemental methods to control radiation exposure. 
- For specific activities, where use of physical design features are demonstrated to be impractical, administrative controls and procedural requirements are used to maintain radiation exposures ALARA.

- Radiation and airborne activity levels are minimized in routinely occupied areas of the solidification and support facilities and in the vicinity of equipment expected to require the attention of personnel.

- Whole-body radiation dose goals to personnel are maintained below $500 \mathrm{mRem}$ per year/per person and ALARA, as required by DOE/EH-0256T.

- Exposure levels to personnel are maintained below an average of $0.5 \mathrm{mRem}$ per hour in full-time occupied areas ( 22,000 hours per year) while maintaining ALARA principles and, where occupancy differs from the above, the exposure levels to personnel are maintained less than $1,000 \mathrm{mRem}$ per year/per person while maintaining ALARA principles, as required by 10 CFR 835 .

Both equipment and facility designs are considered in maintaining doses ALARA during operation, including normal operation, maintenance and repairs, in-service inspection, and calibrations.

\subsubsection{Equipment Design Considerations for ALARA}

Equipment design considerations minimize the time necessary for personnel to remain in areas with elevated radiation levels. Minimizing the amount of time includes:

- Incorporating design features and constructing equipment, components, and materials to reduce the need for repair or preventive maintenance

- Providing maintenance and procedures (including easy disassembly and the use of modular components) so that repairs can be made in areas with the lowest possible radiation levels

- Remotely or mechanically operating, repairing, servicing, monitoring, and inspecting equipment where practicable

- Providing redundant equipment or components to reduce the need for immediate repair or maintenance where radiation or airborne radioactivity levels may be high

- Providing override features on remote handling equipment in radiation areas

- Selecting materials that facilitate operations, maintenance, decontamination, and decommissioning.

\subsubsection{Facility Layout Design Considerations for ALARA}

Optimization methods are used to provide confidence that occupational exposure is maintained ALARA in developing and justifying Facility design and physical controls in accordance with DOE Orders and 10 CFR 835. Facility design considerations to minimize the amount of time personnel spend in radiation areas, as required by WVDP-163, include:

- Locating equipment and instruments that require routine maintenance, calibration, operation, or inspection in easily accessible areas in order to minimize the amount of time needed to perform those operations 
- Separating radioactive or potentially radioactive equipment from nonradioactive equipment

- Providing for the transportation of equipment components requiring service to areas with lower radiation levels

- Separating radiation sources from occupied areas (e.g., developing designs so that pipes and ducts containing potentially radioactive fluids do not pass through normally occupied areas)

- Providing adequate shielding between radiation sources, and access and service areas

- Providing central control panels to permit remote operation of all essential instrumentation and controls from the lowest radiation zone practicable

- Providing means for controlling contamination and airborne radioactivity by proper design of the ventilation system (i.e., designing air flow rate, velocity, and flow patterns for maximum confinement efficiency)

- Designing the surfaces that are subject to possible contamination so they are free of crevices and sharp edges, and coating them to facilitate decontamination.

\subsection{ALARA Operational Considerations}

In accordance with the policy contained in WV-984 and consistent with the requirements contained in DOE Orders and 10 CFR 835, recommendations of DOE Implementation Guide G-10 CFR 835/B2 and DOE/PNL6577, the radiation exposure to personnel is kept ALARA by the Facility design, continued review of operations and training, and the functioning of the Radiological Control organization. In addition to planning, training, and monitoring all activities related to radiation exposure of personnel, some of the ALARA techniques used to reduce exposures are:

- Work is performed outside radiation areas to the extent practicable

- Entry and exit points are located in areas where dose rates are as low as practicable

- Shielding is used whenever possible. Temporary shielding is also used for operations near radiation sources.

- Work is preplanned when it involves whole-body exposure to high levels of radiation or contamination. This provides for expeditious performance of the work activity in a safe manner and with minimum personnel.

- When required, protective clothing and respiratory equipment are worn for radiological protection and selected to minimize the discomfort of workers so that efficiency is maintained and less time is spent in radiation areas

- Workers entering radiation areas where significant doses could be received wear self-reading dosimeters so that they can determine their accumulated exposure at any time while on the job

- Areas with potential for significant loose contamination of airborne radioactivity are isolated by air locks and/or airflow control to minimize inhalation exposure and the potential for the spread of contamination. 


\subsection{RADIATION SOURCES AT THE WVDP}

Radiation sources vary from system to system and are addressed in WVNS Safety Analysis Reports (SARs), as well as radiation safety programmatic documents and technical basis documents that discuss justifications for using radionuclide limits, personnel bioassay sampling and measurements, airborne sampling and measurements, etc. During the former operation of the spent nuclear fuel reprocessing facility, reprocessing wastes and contamination were generated, resulting in high-level, transuranic, and low-level wastes in various buildings, nearby land and structural storage areas, and systems. While many of the shorter-lived radionuclides from the spent nuclear fuel have decayed, the radiation sources present in various operating systems and facilities, addressed in radiation safety documents and SARs, stem from the longer-lived radionuclides remaining from the reprocessed spent nuclear fuel.

Major beta-emitting radionuclides of concern are strontium-90, cesium-137, technicium-99, hydrogen-3, and their associated radioactive decay products. Gamma-rays typically accompany the beta particles during radioactive decay, although strontium- 90 and its decay product are pure beta radiation emitters. Major alphaemitting radionuclides of concern are isotopes of uranium and plutonium, as well as other actinide series. elements such as americium-241, thorium-232, and their lengthy series of radioactive decay products, which also include beta-gamma emitters. 


\subsection{RADIATION SAFETY DESIGN FEATURES}

Specific radiation safety design features are described and discussed in WVNS SARs for the WVDP facilities. Because the WVDP has made the maximum feasible use of the former nuclear reprocessing facilities, many radiation safety design features in the Main Reprocessing Building and systems and other existing facilities are based on original Facility structural and process designs. Additions and modifications to and/or enhanced design features to these buildings and/or systems were used when necessary. The radiation safety design features that are addressed in SARs stem from either original, modified, or added design features.

Requirements for radiation safety design features are integrated into the ALARA Program requirements and originate from DOE Orders, $10 \mathrm{CFR} 835$, and DOE/EH-0256T, and are implemented in WVDP-010. 


\subsection{OCCUPATIONAL RADIATION DOSES}

The on-site occupational dose assessment for a given system or operation is presented in individual WVNS SARs and for any given calendar year, radiological performance goals, including occupational doses, are tracked and reported to all managers and supervisors by the Radiation Protection Department through internal correspondence. In the actual operation of each system, the radiological performance goal of collective occupational dose is predetermined for annual exposures resulting from routine operation and maintenance of that system. The collective occupational dose radiological performance goal is based upon WVNS administrative control levels and the ALARA process and is monitored monthly for higher exposure groups (i.e., with monthly dosimeter badge exchanges) or quarterly for all others to provide confidence that excessive exposures are not being accrued. In the event that the collective occupational dose radiological performance goal is being exceeded, the operation is flagged for additional management attention and/or evaluation. Figure 4-1 presents the total occupational radiation dose received each calendar year by workers at the WVDP from 1982 through 1996.

In the early stages of the Project, essentially from 1982 through 1987, decontamination activities in a number of former process cells were conducted to prepare the Facility for waste treatment processes that utilized existing areas of the Main Plant Reprocessing Facility. Also, spent nuclear fuel assemblies that were being stored in the Fuel Receiving and Storage Area of the Main Plant were shipped from the site back to the original owners (mainly utility companies), with the exception of 125 assemblies that are awaiting shipment to another DOE facility. These activities resulted in higher doses to the workers than what was observed later in the Project, such as during the operation of the Integrated Radwaste Treatment System (IRTS) (the decontamination and solidification of the high-level waste supernate and sludge-washing activities), construction of the Vitrification Facility, and preparation of the Main Plant Facility for vitrification activities during the late 1980 s and early 1990 s.

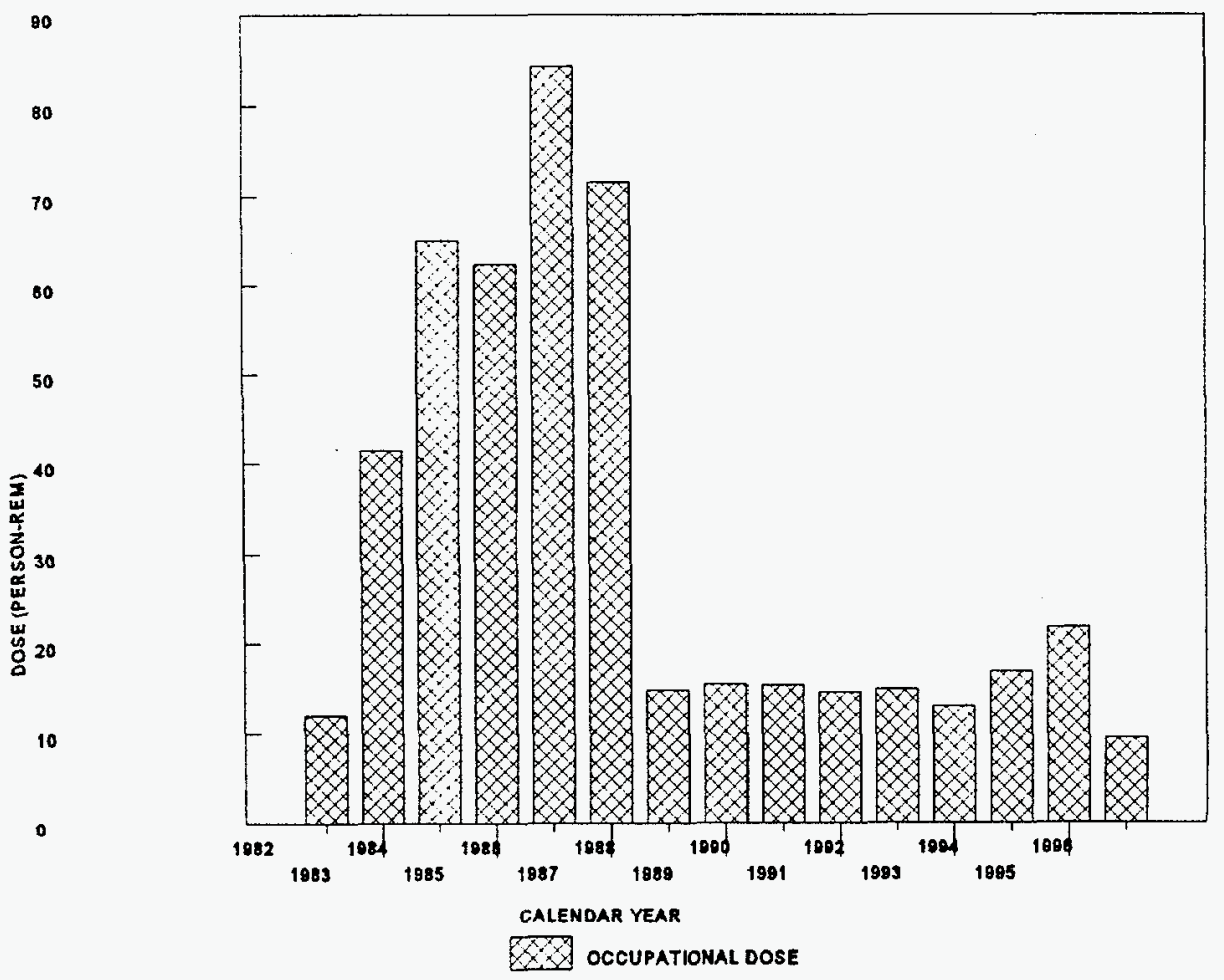

Figure 4-1. Occupational Radiation Dose Received by Workers at the WVDP 


\subsection{RADIATION SAFETY ORGANIZATION}

Implementation of the Radiation Safety Program is an operating line management responsibility and is set forth in WVNS Policy and Procedure WV-905, "Radiological Protection and Nuclear Criticality Safety."

Development of the Program is the responsibility of the Vice President for Environmental, Safety, Health, and Quality Assurance (ESH\&QA) who is assisted by the Radiation Protection Manager. The WVNS Radiation and Safety Committee is responsible for the development of policies and procedures relative to the independent safety review program, which includes radiation safety considerations for operations and activities. This independent review program, established by WVNS Policy and Procedure WV-906, "Radiation and Safety Committee," requires the formation of ad hoc committees to conduct objective reviews of significant modifications to programs or facilities, including radiation safety.

In addition to those staff members directly committed to the WVDP, support is available, if necessary, from other occupational safeguards consulting organizations and from other operating divisions of the Westinghouse Electric Corporation. The functions and responsibilities of the radiation safety-related organizations and the organizational structure and duties of the staff that provides Radiation Safety Program management are described below.

\subsection{Vice President for Environmental, Safety, Health, and Quallty Assurance}

The Vice President for ESH\&QA is responsible for all activities concerning radiological protection of employees, on-site visitors, the general public, and the environment, in accordance with WVNS Policy and Procedure WV-905. The Vice President for ESH\&QA is responsible for developing training programs to instruct workers in performing their jobs safely. The Vice President for ESH\&QA reports to the WVNS President and has the full authority to cease operations in the event that operating conditions are not in compliance with operational radiological safety controls or approved operating procedures.

\subsection{Radiation Protection Manager}

The Radiation Protection Manager reports to the Vice President for ESH\&QA and is responsible for maintaining radiological safety of the site by regularly evaluating and assessing surface contamination, radiation levels, and airborne radioactivity concentrations in work areas with respect to approved limits, in accordance with WVNS Project Document WVDP-010, "WVDP Radiological Controls Manual." A major responsibility of this organization is to assist operating management in developing programs and plans to maintain radiation exposures ALARA. Cost effectiveness or optimization of these programs is considered in the development and justification of design and physical controls. The Radiation Protection Manager is responsible for:

- Ensuring that a personnel dosimetry program is in place to determine radiation exposures of employees and visitors who are authorized to receive occupational radiation exposure and that records of such exposures are properly maintained and reported

- Ensuring proper calibration and maintenance of the radiological control instrumentation used in normal or emergency operations

- Ensuring that radiological surveys and monitoring are performed in the workplace and that internal and external exposure controls are adequate in protecting individuals within exposure limits and ALARA 
- Removing those employees who have exceeded the established Facility administrative control levels from the list of employees authorized to receive additional occupational radiation exposure

- Removing from the list of employees authorized to receive occupational radiation exposure those personnel who have not demonstrated their continuing understanding of the Project's radiological safety-related operating procedures or the need for compliance with them

- Reviewing Facility and process design, operating procedures, and design and process changes, and providing engineering support to operational groups that prepare those procedures.

The Radiation Protection Manager and staff have the authority and responsibility to cease operations in the event they are not proceeding in accordance with established operating procedures and safety controls, or they involve an unreviewed operation that presents a safety risk. The Radiation Protection Manager maintains WVDP-010, which implements the policies contained in WV-905. Radiological control procedures are contained in the WVNS Service Manual WVDP-131, "Radiological Control Procedures," and provide details to the Radiation Protection Department in implementing Radiation Protection Program requirements. Program manuals and technical basis documents are developed by the Radiation Protection staff to describe a specific program's requirements and also to provide a rationale or background for calculations, measurement frequencies, etc., for such programs.

The Radiation Protection Manager is also responsible for reviewing Facility operations that involve fissile material storage, processing, handling and shipping, and developing and implementing a control and monitoring program to prevent accumulating unsafe quantities of nuclear materials. The Radiation Protection Manager is responsible for ensuring that nuclear criticality alarm instrumentation, nuclear accident dosimeters, and an effective, well-documented analysis program and review system are in place if and when conditions require such monitoring. In compliance with WVNS policy, these systems will meet or exceed the DOE requirements for nuclear criticality safety of nonreactor nuclear facilities described in DOE Order 5480.24, "Nuclear Criticality Safety," and DOE-mandated American National Standards. The program is implemented by the WVDP in WV-905 and WVNS Project Document WVDP-162, "Nuclear Criticality Safety Program Manual."

\subsection{Radiation Protection Staff}

WVNS management has provided a staff of radiological protection and nuclear criticality safety professionals to administer those radiation safety policies that are related to specific organizational duties. In general terms, the radiation safety-related responsibilities of the Radiation Protection organization are to:

- Establish, interpret, and implement the radiation safety program and policy requirements

- Adopt and interpret applicable codes, standards, and guides

- Provide radiation safety services for employees

- Provide training support

- Support an emergency response capability

- Support line organizations with radiation safety matters

- Collect, evaluate, and disseminate radiation safety-related information 
- Support hazard and risk assessment and systems' safety programs.

Reporting to the Radiation Protection Manager are Radiological Control Operations Supervisors and the Radiological Engineering Manager. Under the Radiological Control Operations Supervisors are Radiological Control Technicians, who provide routine monitoring and surveillance functions. The Radiological Engineering staff, which includes Health Physicists and other professionals and technical support personnel within the Radiation Protection Department, provide technical support to the Radiological Controls Operations groups, if needed. The Radiological Engineering Manager is assisted by the staff in establishing, developing, and maintaining the Radiation Protection Program in compliance with DOE and management requirements, including those requirements as established in WVDP-010.

\subsection{Facllity Operatlons}

The Radiation Protection Organization provides support to Operations, Maintenance, and other technical support groups in the area of radiation safety training and radiological emergencies (i.e., the Radiological Control Team). The Radiation Protection Department develops radiation safety training programs, qualification standards and questionnaires for use in general employee and radiological worker training, nuclear criticality safety training, radiation safety orientation for on-site visitors, and respiratory protection training. The Radiation Protection Department also conducts radiation safety training programs in: general employee and radiological worker training, the use of containment devices, nuclear criticality safety training, radiation safety orientation for on-site visitors, and respiratory protection training. Training records are maintained in a central file by the Records Management Department.

The Radiation Protection Manager is responsible for providing radiological control support to the WVNS Emergency Management Department in implementing the requirements of the applicable 5500 series DOE Orders covering emergency management and response. The Radiation Protection Staff also performs duties for the DOE Radiological Assistance Program (RAP) coordinated by Brookhaven National Laboratory for Region I which includes the eleven Northeastern states.

\subsection{Radiation and Safety Committee}

WVNS Policy and Procedure WV-906, "Radiation and Safety Committee," establishes the Radiation and Safety Committee (R\&SC), a group of individuals appointed by the WVNS President to provide objective and independent review of safety-related operations, systems, and activities. The R\&SC, which functions in an advisory capacity to the line organization and the WVNS President, provides an independent review of significant modifications to programs and facilities to provide confidence that:

- Radiation safety matters are comprehensively addressed in formal documents and reports submitted for review

- Risks have been identified and are acceptably low with respect to the benefits gained

- Management authorization of operations is documented.

The R\&SC is staffed by standing and ad hoc members. When items or activities are being reviewed, the member(s) who is cognizant of the item(s) or activity is not allowed to vote for approval. The R\&SC Chairperson and the standing and ad hoc committee members are appointed by the WVNS President. The R\&SC reports directly to the WVNS President. 


\subsection{RADIATION DETECTION EQUIPMENT, INSTRUMENTATION, AND SUPPORT FACILITIES}

The instrumentation used by Radiological Control personnel can be divided into four categories:

- Fixed radiation counting instruments

- Portable radiation detection instruments

- Area radiation monitoring instruments

- Airborne radioactivity sampling and monitoring instruments.

Instruments are consistent throughout the WVDP facilities. Instruments are repaired and calibrated by instrument maintenance and calibration personnel in the Radiation Protection Department. In some cases, specialized instruments may be returned to the manufacturers for repair and calibration.

\subsection{Radiation Counting Instruments}

Fixed radiation-counting instruments are used primarily for analyzing air, water, soil, and smear samples taken in and around the WVDP facilities. The instruments selected for use by the Radiation Protection Department and in the laboratories possess sensitivities to detect levels required by the operating technical specifications and good operating practices.

These instruments are periodically calibrated with standard sources traceable to the National Institute of Standards and Technology (NIST) or other recognized standards laboratories. The standards are counted using the various geometries that are normally used to count actual samples. Instrument background and response to calibration and/or check sources is determined each operating day to verify that the instrument background and calibration have not changed beyond predetermined acceptable instrument response ranges.

The type of fixed radiation-counting instrument used by the Radiation Protection Department is a low-background, gas-flow, proportional counter that consists of an anticoincidence guard detector with lead shield, automatic sample changer, and electronics to permit simultaneous counting of alpha and beta radiations. The counters are used for low-level alpha and beta determinations of air, smear, soil, and water samples.

The laboratory instrumentation, located on the third floor of the Process Building, is operated by the Analytical and Process Chemistry (A\&PC) Department, the Environmental Laboratory is operated by a subcontractor (Dames \& Moore) in the Environmental Laboratory. All are under the cognizance of the ESH\&QA organization. The instrumentation consists of:

- Germanium lithium (GeLi) and hyperpure germanium (HPGe) detectors for gamma and X-ray spectroscopy

- Gas-proportional alpha/beta counters

- Surface barrier-type semiconductor detectors for alpha spectroscopy

- A liquid scintillation counter 
- Microprocessor-based multichannel analyzers, a line printer, an X-Y plotter, and associated electronics and software that can be interfaced with all of the above detectors for spectrum display and analysis, and data printout.

Samples are prepared by A\&PC Laboratory personnel for counting in the Radiochemical Laboratory and environmental samples are prepared by Environmental Laboratory personnel in their laboratory. Sample preparation for counting may include solidification, chemical separation, and loading samples into appropriate containers.

\subsection{Portable Radiation Detection Instruments}

Portable radiation detection instruments are used by the Radiation Protection Department to perform radiation and contamination surveys in the field. Portable instruments include those capable of detecting alpha, beta, gamma, and neutron radiation. Instruments are selected based on ruggedness, accuracy, reliability, and ease of service. These instruments cover the entire spectrum of radiation measurements expected to be required during normal operations and emergency conditions.

Portable instruments are normally calibrated semiannually using appropriate NIST-traceable radiation sources as required by the DOE-mandated American National Standard ANSI N323, "Radiation Protection Instrumentation Test and Calibration." The DOE Implementation Guide G-10 CFR 835/E1, "Instrument Calibration for Portable Survey Instruments," provides an acceptable methodology for establishing and operating a program for calibrating portable radiological survey instruments. Requirements for calibration are incorporated into radiological control procedures. For the WVDP, radiation detection instrument calibration may be performed either on site by Radiation Protection personnel or off site by the instrument manufacturer or vendor.

\subsubsection{Alpha Detection Instruments}

Portable alpha detection instruments used at the WVDP are scintillation-type detectors. These detectors have efficiencies that range between 10 and 15 percent for $\mathrm{Pu}-239$ and are intended for field use in making surface and personnel contamination surveys. The geometry of the detectors makes them suitable for use in both removable and total contamination surveys. In addition to the detectors, a portable ratemeter and/or scaler is provided for scanning and/or fixed-point measurements. Scanning rates and counting times are established so that the minimum detectable activity of these instruments is less than the contamination limits specified in DOE documents, such as, 10 CFR 835, DOE Order 5400.5, and DOE/EH-0256T. WVNS Project Document WVDP-234, "WVDP Workplace Radiological Surface Measurements Program and Technical Basis Document," provides the rationale and calculational methods used in performing and analyzing surface radioactivity measurements for alpha- emitting radionuclides.

\subsubsection{Beta Detection Instruments}

Beta detectors and suitable ratemeters are widely used for both surface and personnel contamination control at the WVDP. The primary detectors used in these applications are thin-window Geiger-Mueller (G-M) tubes. The thin-window G-M tubes have efficiencies ranging between 16 and 21 percent for Sr-90/Y-90. Scanning rates and counting times are established so that the minimum detectable activity of these instruments is less than the contamination limits specified in DOE documents, such as, 10 CFR 835, DOE Order 5400.5, and DOE/EH-0256T. WVNS Project Document WVDP-234 provides the rationale and calculational methods used in performing and analyzing surface radioactivity measurements for beta-emitting radionuclides. 


\subsubsection{Gamma Detection Instruments}

Scintillation detectors and ionization chambers are used for gamma radiation surveys. Ionization chambers with movable beta shields that cover the active area of the detector allow discrimination between penetrating and nonpenetrating radiation (i.e., deep and shallow dose). Both directional and nondirectional detectors are provided. These detectors are used for both field contamination and direct radiation surveys. Low-, medium-, and high-range instruments are available as follows:

- Low-range instruments are normally used for background monitoring outside of areas where radioactive materials are handled. They use either scintillation or high-pressure ionization chambers as detectors. The range of detection is 0.1 milli-Roentgen per hour $(\mathrm{mR} / \mathrm{hr})$ to 5 Roentgen per hour $(\mathrm{R} / \mathrm{hr})$.

- Medium-range instruments are hand-held survey instruments used for general area radiation surveys. They have a range of $0.1 \mathrm{mR} / \mathrm{hr}$ to $50 \mathrm{R} / \mathrm{hr}$ and use either ionization chambers or scintillation detectors.

- High-range instruments fitted with telescoping probes are available for monitoring high-level radiation sources. In general, they have probes that can be extended over 10 feet to reduce exposure to the technician making the measurement. These instruments are either G-M tubes or solid state detectors not subject to saturation at high fluxes and have ranges from $0.1 \mathrm{mR} / \mathrm{hr}$ to $1,000 \mathrm{R} / \mathrm{hr}$.

Radiation exposure rate measurements are performed so that radiation levels are known and personnel exposures can be maintained less than the exposure limits specified in DOE documents, such as, 10 CFR 835, DOE Order 5400.5, and DOE/EH-0256T. WVNS Project Document WVDP-234 provides the rationale for usage and the calculational methods for detection limits used in performing and analyzing gamma radiation measurements.

\subsubsection{Neutron Detection Instruments}

Neutron detection instruments are portable instruments available for neutron surveys incorporating tissueequivalent, polyethylene-cadmium shielded, $\mathrm{BF}_{3}$-type detectors. These instruments are calibrated to read directly in $\mathrm{mRem}$ per hour and have a range of $0.1 \mathrm{mRem} / \mathrm{hr}$ to $2 \mathrm{Rem} / \mathrm{hr}$.

\subsection{Airborne Contamination Sampling and Monitoring Equipment}

Sampling for airborne contamination is accomplished using both fixed and portable devices and is discussed in WVNS Project Document WVDP-216, "WVDP Workplace Radiological Air Sampling and Monitoring Program and Technical Basis Document." The DOE Implementation Guide G-10 CFR 835/E2, "Workplace Air Monitoring," provides an acceptable methodology for establishing and operating a workplace air monitoring program that will comply with $10 \mathrm{CFR} 835$ and DOE/EH-0256T requirements. DOE requirements are incorporated into both WVDP-010 and WVDP-216 as well as radiological control procedures.

The fixed instrumentation consists of low-volume air samplers mounted on the walls near breathing zone heights throughout the Plant. The Plant vacuum system continuously draws air through fixed filter papers in these samplers at a flow rate of approximately 28.3 liters per minute (lpm) or 1.0 cubic foot per minute (cfm).

Portable instrumentation used for airborne contamination sampling consists of continuous air monitors (CAMs) 
and hand-held, high-volume air samplers. The CAMs are located near the workers' operational areas and provide representative samples of the concentrations to which personnel are exposed. They continuously collect and measure airborne particulates by pumping air through a fixed filter, at approximately 28.3 liters per minute, in close proximity to an integral beta-gamma detector or alpha detector. The flow rate may be adjusted to the desired level, and pulse height discriminators and background subtraction features available on some of the models lessen the sensitivity of the detectors to short-lived radon and thoron daughter interference. Meters, strip chart recorders, audible alarms, and alarm lights provide a clear, permanent record and unambiguous indication of alarm conditions. Ranges are switched automatically. Each monitoring system is capable of measuring one derived air concentration (DAC) when averaged over 8 hours ( 8 DAC-hours) under laboratory conditions. However, under normal operating conditions, interference from radon and their progeny have caused actuation of CAM alarms; therefore, alarm set points of up to 24 DAC-hours are considered acceptable but are set at the lowest practical level, specific to a location, without causing a significant number of false alarms (i.e., one alarm per month per unit).

Portable high-volume air samplers operate with much higher flow rates than the CAMs or the fixed Plant air samplers. They operate on battery power or line voltage. Air is drawn through a fixed filter paper. Interchangeable filter holders of varying sizes are used in conjunction with filters of matching sizes and varying materials depending on the particular application.

Flow-rate measuring devices on stationary and portable air samplers are calibrated annually using flow- rate calibration equipment. The flow-rate calibrators are calibrated annually by the manufacturer with NISTtraceable calibration standards. CAM detectors are calibrated annually using NIST-traceable calibration standards.

\subsection{Personnel Monltoring Instruments and Servlces}

Instruments are used to measure the radiation dose received by personnel and to detect external and internal contamination. Monitoring of personnel at the exit of contaminated areas for external contamination is performed using the survey instruments previously discussed. In addition, personnel contamination monitors (PCMs) or hand-held probes are placed at all exits from Radiological Buffer Areas and personnel are responsible for conducting a whole body survey each time they leave such an area.

Personnel monitoring for external dose uses thermoluminescent dosimeters (TLDs). TLDs are processed in an automatic TLD reader. The TLD reader is calibrated both electronically and with elements exposed to known doses from NIST-traceable sources prior to processing TLDs. The external dosimetry program is accredited under the Department of Energy Laboratory Accreditation Program (DOELAP) in accordance with DOE Order 5480.15, "DOE Laboratory Accreditation Program for Personnel Dosimetry." The DOELAP process requirements are defined in DOE/EH-0026, "Handbook for the Department of Energy Laboratory Accreditation Program for Personnel Dosimetry Systems," and DOE/EH-0027, "Department of Energy Standard for the Testing of Personnel Dosimetry Systems."

In addition to the TLD badge, ionization chamber direct-reading pocket dosimeters are issued to those workers on the monthly badge processing schedule. The direct-reading dosimeters and TLDs are worn continuously by these employees while they are in radiologically controlled areas. In some special cases, digital electronic alarming integrating dosimeters are used in addition to the standard-issue dosimetry.

A whole-body counting facility for internal dose assessment is located in the WVDP Dosimetry Office. In vivo measurements are made using a gamma spectroscopy whole-body counter. The in vivo dosimetry program participates in the conduct of intercomparison studies and uses the "DOE Phantom Library." Urine samples for in vitro measurements are collected from monthly dosimetry-badged workers and those using respiratory 
protection in radiologically controlled areas. These bioassay samples are shipped to a subcontracted laboratory for radioanalysis. Containers for both urine samples and fecal samples are available at the site, and service subcontracts are established for handling both routine and nonroutine bioassay samples.

\subsection{Instrument Storage, Calibration, and Maintenance Facilities}

Portable radiation detection instruments are stored in the Radiological Control Operations Shift Office. The Project maintains a Radiological Instrument Calibration Facility. In addition to other equipment, this Facility possesses a gamma calibrator with a retractable shielded Cs-137 source capable of producing radiation fields greater than $400 \mathrm{R} / \mathrm{hr}$ inside a small portion of the shielded calibration cavity; the corresponding external dose rate is $0.1 \mathrm{mR} / \mathrm{hr}$ at 1 meter. Instrument maintenance is also performed in the Calibration Facility, with out-of-service instruments stored while awaiting calibration/service.

\subsection{Radioactive Material Analysis Facilities}

Radiological laboratory facilities are available in the third floor Analytical Chemistry Laboratory and includes a Radiochemical Laboratory. The Radiochemical Laboratory is managed and operated by professional chemists and trained chemistry technicians. The Environmental Laboratory is located south of the Administration and Annex Complex and is equipped with counting instruments similar to the Analytical Chemistry Laboratory. The Radiation Protection Department Laboratory, located on the second floor of the Main Plant, provides a laboratory hood, scales, etc., and counting equipment for Radiological Control Technicians. Fixed radiation counting instruments are located in these facilities, as well as in several areas throughout the plant, for radiological counting of air sample filters and smears by Radiological Control Technicians and was discussed previously in Section 6.1.

\subsection{Radiological Control Equipment, Clothing, and Associated Facilities}

Personnel protective equipment (PPE) and clothing are supplied on an as-needed basis to protect personnel from contamination. The protective equipment provided includes:

- Body protection - lab coats, anti-contamination (anti-C) coveralls, plastic suits, body-cooling suits, and/or supplied air, as appropriate

- Head protection - cloth and plastic hoods

- Hand protection - disposable gloves, surgeon's gloves, rubber gloves, and glove liners

- Foot protection - plastic shoe covers, rubber overshoes, and boots.

Protective clothing is stored at the Laundry Facility for normal work activities and entries into radiological areas of the Facility. Protective clothing is removed when personnel exit a contaminated area; clothing designated for use in contaminated areas is not permitted to be worn elsewhere in the Facility. Used protective clothing is stored in plastic hampers at the change point until disposal of nonreusable items (e.g., paper suit, tape, etc.) or transport to the Laundry Facility of reusable items (e.g., cloth anti-C coveralls, hoods, rubber shoe covers, etc.). 
Contamination control equipment is used to prevent or limit the spread of radioactive contamination and to assist in its removal. The equipment includes:

- Polyethylene sheeting

- Disposable absorbent towels

- Plastic bags of assorted sizes

- Clothbacked tape

- Radiation and contamination warning signs

- Barricade posts with magenta and yellow-colored rope

- Air locks and tents for manned entry/exit and work in highly contaminated areas. The air locks/tents are fabricated by a vendor according to WVNS specifications, as needed, for decontamination and decommissioning activities.

- Custom glove boxes, also designed on an as-needed basis, for entry/exit of remotely controlled equipment into/out of highly contaminated areas.

When possible, this equipment is stored in closets and cabinets at control points, and in or near other areas where it is routinely used. Larger items are stored in the Warehouse until needed at a jobsite.

\subsection{Respiratory Protection Equipment}

A variety of types of respiratory protection equipment for decontamination and decommissioning activities, waste solidification and management operations, maintenance activities, and emergency use are available at the WVDP. High-efficiency, air-filtered, chemical absorbent, and atmosphere-supplied respiratory devices are routinely used. A quantitative respirator fit test is used to measure the fit of a respirator on an individual using the DOE-mandated ANSI Z88.2 and OSHA (29 CFR 1910) fit-testing protocols. The fit-test equipment measures ambient air concentrations inside and outside the mask while the individual performs a variety of exercises. The equipment is sensitive enough to verify fit factors up to 100,000 for individuals.

Only equipment approved for use by the National Institute of Occupational Safety and Health (NIOSH) under 42 CFR 84, "Approval of Respiratory Protective Devices," are used at the WVDP. Respiratory equipment is cleaned, examined, repaired, and leak-tested by trained personnel in accordance with standard operating procedures (SOPs). The use of respiratory equipment is described in the SOPs and are available for use as follows:

\subsubsection{Alr Particulate Removing Respirators}

Particulate removing respirators protect individuals against inhalation of airborne particles in the form of aerosols including dusts, sprays, fumes, smoke, and mists. They consist of both positive pressure and negative pressure masks and typically consist of one or two high-efficiency particulate air (HEPA)-filtered cartridges. While both half- and full-face respirators are available at the WVDP for protection against radionuclides, fullface respirators are used at a minimum. 


\subsubsection{Gas and Vapor Removing Respirators}

Chemical cartridge respirators typically consist of a single canister or two cartridges containing granular absorbents or catalysts attached to the facepiece. These respirators protect against lower concentrations of vapors and/or gases such as acid gases, ammonia, organic vapors, and solvent vapors.

\subsubsection{Supplied-air Respirators}

A source of compressed air supplies respirable air through a small-diameter hose to the wearer of an airline respirator. The full-face airline respirator is used for a wide variety of airborne contaminants, including higher concentrations of particulates, gases, and vapors. The airline hose is connected to an apparatus on the individual that contains a backup cartridge or canister in the event of a loss of supplied air, and for use during protective clothing doffing procedures after being disconnected from the air source.

\subsubsection{Self-contained Breathing Apparatus}

A self-contained breathing apparatus (SCBA) is a respirator that employs a supply of air carried by the individual to provide him/her with respirable air. SCBAs offer respiratory protection against unknown or higher concentrations of vapors, gases, particulates, and combinations thereof, with an assigned protection factor of 10,000 used. SCBAs are also used in known or potential oxygen-deficient atmospheres. SCBAs are placed in strategic locations throughout facilities at the WVDP and are inspected on a monthly basis.

\subsection{Equipment and Personnel Decontamination Facillties}

If required, contaminated tools and equipment are decontaminated in the Remote Manipulator Repair Shop. Any water and detergents used in the decontamination process is routed to the Low-level Waste Treatment Facility.

Anti-C clothing is decontaminated in the WVDP Laundry Facility. Respirators are decontaminated, sanitized, and refurbished (if necessary) at the Laundry Facility. After passing examinations and inspections required by DOE-mandated ANSI Z88.2 and OSHA (29 CFR 1910), respirators are bagged and tagged ready for use and stored in the Laundry Facility or near the work area.

A personnel decontamination facility is available on site with an alternate facility located off site at the Bulk Storage Warehouse. The on-site personnel decontamination facility is located on the second floor of the Process Building in the Chemical Viewing Aiste. The on-site facility contains a shower and two sinks, and is equipped with the appropriate personnel decontamination chemicals and detergents. Drains are directed to the Low-level Waste Treatment Facility.

In addition to these exclusive-use facilities, showers and eyewash stations are placed at various locations throughout the Process Building and other buildings as necessary. 


\subsection{RADIOLOGICAL CONTROL PROGRAMS AND PROCEDURES}

\subsection{Radiation and Contamination Surveys}

Radiological Control Technicians perform routine radiation and contamination surveys of all accessible areas of the Facility. Survey areas and frequencies are determined in accordance with DOE/EH-0256T and WVDP010 , as well as site-specific requirements contained in WVDP-131, "Radiological Control Procedures." They are based upon the probability of contamination, changes in radiation levels, and personnel occupancy. These surveys consist of radiation measurements and/or total and removable contamination measurements as appropriate for the specific area. The records of the survey results are retained by Radiation Protection and are reviewed periodically so that trends indicating problem areas are identified as early as possible.

Direct radiation surveys are performed using portable instruments in accordance with the following criteria:

- Appropriate radiation surveys are performed periodically to control radiation doses during solidification, and decontamination and decommissioning activities.

- Routine gamma radiation surveys are performed at frequencies specified by DOE/EH-0256T and WVDP-010.

- Gamma radiation surveys are performed in spaces surrounding radiation areas subsequent to the movement of radioactive equipment or material. The boundaries are adjusted as necessary.

- Boundaries of radiation areas that are established for a specific, short-term purpose are surveyed each work day that activities are performed during which radiological conditions might change.

Radiation Protection staff establishes and maintains a routine schedule for surface contamination surveys similar to direct radiation surveys. Requirements and guidelines for the conduct of contamination surveys are provided in DOE/EH-0256T and WVDP-010. The survey schedule defines the area to be surveyed and the frequency of the survey. In general, areas with a higher potential for contamination are surveyed more frequently than areas with a lower contamination potential. In addition, sufficient surveys are taken during work involving radioactive material handling to provide confidence that contamination control is maintained.

Two types of contamination surveys are made: surveys performed with portable instruments or total contamination measurements, and smear surveys or removable contamination measurements using fixed laboratory counting instruments for analyses. For any item to be removed from a radiologically controlled area, portable instruments are used to determine the amount of total (fixed) contamination deposited on the surface. The probe is placed in close proximity to the surface being surveyed and the total amount of radioactivity detected by the instrument is averaged over the active area of the probe. These probe surveys are followed by removable contamination measurements made by wiping a $100 \mathrm{~cm}^{2}$ area with wipes and then analyzing the wipes in the Counting Laboratory to determine the amount of gross alpha and beta activity wiped from the potentially contaminated surface. Results are compared with the maximum allowable surface radioactivity levels permitted outside the contaminated areas. Limits for removable contamination for accessible surfaces within clean areas are specified in DOE documents such as 10 CFR 835, DOE/EH-0256T and DOE Order 5400.5, as well as WVDP-010.

The survey methods discussed above are capable of detecting activities below the applicable surface radioactivity limits. Based on the results of these surveys, areas are posted and controlled in accordance with the criteria discussed in Section 7.3. All radiological survey records are maintained in accordance with 10 CFR 835, DOE/EH-0256T, and DOE-mandated ANSI N13.6, "Practice for Occupational Radiation Exposure 
Record Systems." The DOE Implementation Guide G-10 CFR 835/H1, "Occupational Radiation Protection Record-Keeping and Reporting," provides an acceptable methodology for establishing and operating an occupational radiation protection records and reporting system. These requirements are described in WVDP010.

\subsection{Procedures for Ensuring that Occupational Doses are ALARA}

The objective of the Radiation Protection Program is to provide confidence that the exposure of employees and on-site visitors to radiation and radioactive materials is within the requirements of DOE documents such as 10 CFR 835 and DOE/EH-0256T, and that such exposures are kept ALARA. These objectives are met by ensuring that:

- Personnel receive a level of radiation protection training appropriate to their assignments

- Appropriate access control techniques and protective clothing are used to limit the spread of external contamination

- Engineering and administrative controls are used to control contamination in the workplace and a respiratory protection program is in place with respiratory protective equipment used where required

- Radiation areas are segregated and appropriately posted to limit radiation exposure

- Instruments and equipment are properly calibrated so that accurate radiation, contamination, and airborne radioactivity surveys can be performed

- Appropriate personnel dosimetry devices are supplied and a radiation exposure record system is maintained

- An internal dose assessment program (whole-body counting and/or urinalysis) is in place

- All work in radiation areas, or where there is surface or airborne contamination areas, is preplanned and reviewed from an ALARA standpoint.

\subsection{Access Control}

Access to portions of the Facility is controlled in accordance with DOE requirements established in 10 CFR 835, DOE/EH-0256T, and WVDP-010. The DOE Implementation Guide G-10 CFR 835/G1, "Posting and Labeling for Radiological Control," provides an acceptable methodology for establishing and operating a radiological control posting and labeling program. Personnel entering radiologically controlled areas of the plant must know the radiological control procedures, receive documented training for the specific area or areas as specified in Section 7.5, or be escorted continuously by someone who has received such training. With the exception of escorted general employees and visitors, all personnel entering a radiologically controlled area will wear appropriate dosimetry (Section 6.4). Radiologically controlled areas at the WVDP are accessed through an administrative system of radiation work permits (RWPs) and, for high and very high radiation areas, locks are placed on the entrances to prevent inadvertent entry.

The RWP specifies the controls necessary for the planned entry, such as protective clothing, stay times, respiratory protection, and supplemental dosimetry. The necessity for these controls may be based exclusively on radiation level, a combination of surface contamination and radiation level, the concentration of airborne 
contamination, or the potential for occurrence of any of these conditions. Access and stay time are rigidly controlled for high and very high radiation areas. If conditions are of a nature that manned entry is not warranted, remote techniques are used. The exposure and contamination controls to be specified depend on the nature of the work performed in the area. A stay time or maximum allowable dose for each entry is determined by Radiation Protection and noted on the RWP. In addition to TLD badges, entering personnel may be accompanied by a member of Radiation Protection who continuously monitors the dose rate in the work area.

There are 13 types of radiologically controlled areas defined in the following sections: Radiation Area, High Radiation Area, Very High Radiation Area, Hot Spot, Fixed Contamination Area, Contamination Area, High Contamination Area, Airborne Radioactivity Area, Soil Contamination Area, Underground Radioactive Materials Area, Restricted Access Area, Radioactive Material Area, and Radiological Buffer Area. Posting may include any combination of classifications needed to correctly characterize the area. Personnel who do not enter the above areas are not expected to receive greater than $100 \mathrm{mRem} / \mathrm{yr}$.

\subsubsection{Radiation Area}

A Radiation Area is an area accessible to personnel where there are radiation fields of such levels that an individual could receive in any 1 hour a dose equivalent between $5 \mathrm{mRem}(0.05$ millisievert) and $100 \mathrm{mRem}$ (1.0 millisievert) at a distance of $30 \mathrm{~cm}$ from the radiation source or from any surface through which the radiation penetrates.

Each Radiation Area is posted with a sign meeting applicable standards, including the trefoil radiation symbol and the words CAUTION - RADIATION AREA - PERSONNEL DOSIMETRY REQUIRED FOR ENTRY.

\subsubsection{High Radiation Area}

A High Radiation Area is an area accessible to personnel where an individual could receive, in any one hour, a dose equivalent greater than $100 \mathrm{mRem}(1.0$ millisievert) at a distance of $30 \mathrm{~cm}$, but less than 500 rads ( 5 gray) at a distance of $100 \mathrm{~cm}$ from the radiation source or from any surface through which the radiation penetrates.

Each High Radiation Area is posted with a sign meeting applicable standards, including the trefoil radiation symbol and the words DANGER - HIGH RADIATION AREA - PERSONNEL DOSIMETER, SUPPLEMENTAL DOSIMETER, AND RWP REQUIRED FOR ENTRY.

\subsubsection{Very High Radlation Area}

A Very High Radiation Area is an area accessible to personnel where an individual could receive, in any one hour, a dose equivalent greater than 500 rads ( 5 gray) at a distance of $100 \mathrm{~cm}$ from the radiation source or from any surface through which the radiation penetrates.

Each Very High Radiation Area is posted with a sign meeting applicable standards, including the trefoil radiation symbol, and the words GRAVE DANGER - VERY HIGH RADIATION AREA - SPECIAL CONTROLS REQUIRED FOR ENTRY. 


\subsubsection{Hot Spot}

A Hot Spot is an area where the localized exposure rate made by contact readings is greater than or equal to five times the exposure rate in the general work area and greater than $100 \mathrm{mRem} / \mathrm{hr}$.

Each Hot Spot is posted with a sign meeting applicable standards, including the radiation symbol and the words CAUTION - HOT SPOT. Radiation Protection personnel will provide the exposure rate in the appropriate space on the sign.

\subsubsection{Fixed Contamination Area}

A Fixed Contamination Area is an area that has total contamination levels (fixed plus removable) greater than $1,500 \mathrm{dpm} / 100 \mathrm{~cm}^{2}$ alpha maximum, or $500 \mathrm{dpm} / 100 \mathrm{~cm}^{2}$ alpha averaged over one square meter, or 15,000 $\mathrm{dpm} / 100 \mathrm{~cm}^{2}$ beta-gamma maximum, or $5,000 \mathrm{dpm} / 100 \mathrm{~cm}^{2}$ beta-gamma averaged over one square meter, but with removable contamination levels less than or equal to $20 \mathrm{dpm} / 100 \mathrm{~cm}^{2}$ alpha and $200 \mathrm{dpm} / 100 \mathrm{~cm}^{2}$ betagamma.

Each Fixed Contamination Area is posted with a sign meeting applicable standards, including the trefoil radiation symbol and the words CAUTION - FIXED CONTAMINATION.

Exits from each Fixed Contamination Area do not require a personnel survey unless specified by the Radiation Protection Department; however, when a personnel survey is required, the area must be posted with the words STOP - ALL PERSONNEL - SURVEY REQUIRED UPON EXITING, unless the area is contained within a larger area that has this sign posted at its exits.

\subsubsection{Contamination Area}

A Contamination Area is an area with removable contamination levels greater than one times, but less than 100 times, the following levels: $20 \mathrm{dpm} / 100 \mathrm{~cm}^{2}$ alpha and $200 \mathrm{dpm} / 100 \mathrm{~cm}^{2}$ beta-gamma.

Each Contamination Area is posted with a sign meeting applicable standards, including the trefoil radiation symbol and the words CAUTION - CONTAMINATION AREA.

Exits from each Contamination Area must be posted with the words STOP - ALL PERSONNEL - SURVEY REQUIRED UPON EXITING, unless the area is contained within a larger area that has this sign posted at its exits.

\subsubsection{High Contamination Area}

A High Contamination Area is an area with removable contamination levels exceeding $2,000 \mathrm{dpm} / 100 \mathrm{~cm}^{2}$ alpha or $20,000 \mathrm{dpm} / 100 \mathrm{~cm}^{2}$ beta-gamma.

Each High Contamination Area is posted with a sign meeting applicable standards, including the trefoil radiation symbol and the words DANGER - HIGH CONTAMINATION AREA - RWP REQUIRED FOR ENTRY.

Exits from a High Contamination Area are posted with the words STOP - ALL PERSONNEL - SURVEY 
REQUIRED UPON EXITING, unless the area is contained within a larger area that has this sign posted at its exits.

\subsubsection{Airborne Radloactivity Area}

An Airborne Radioactivity Area is an area accessible to personnel where airborne radioactivity is known to exist or is likely to exist in concentrations greater than $1 / 10$ of the DACs contained in 10 CFR 835 .

Each Airborne Radioactivity Area is posted with a sign meeting applicable standards, including the trefoil radiation symbol and the words CAUTION - AIRBORNE RADIOACTIVITY AREA - RWP REQUIRED FOR ENTRY.

Exits from each Airborne Radioactivity Area are posted with the words STOP - ALL PERSONNEL SURVEY REQUIRED UPON EXITING, unless the area is contained within a larger area that has this sign posted at its exits.

\subsubsection{Soll Contamination Area}

A Soil Contamination Area is an area that has contaminated soil that is not releasable in accordance with DOE Order 5400.5.

Each Soil Contamination Area is posted with a sign meeting applicable standards, including the trefoil radiation symbol and the words CAUTION - SOIL CONTAMINATION AREA - CONTACT RADLATION PROTECTION BEFORE ENTERING.

Exits from each Soil Contamination Area are posted with the words STOP - ALL PERSONNEL - SURVEY REQUIRED UPON EXITING, unless the area is contained within a larger area that has this sign posted at its exits.

\subsubsection{Restricted Access Area}

A Restricted Access Area is an area that requires special radiological precautions for entry. Entry into a Restricted Access Area shall require the approval of Radiation Protection.

Each Restricted Access Area is designated by a sign with the words CAUTION - RESTRICTED ACCESS AREA - APPROVAL REQUIRED FOR ENTTRY - CONTACT RADIATION PROTECTION.

\subsubsection{Radioactive Material Area}

A Radioactive Material Area is an area where radioactive materials, as defined by WVDP-010, are present. Each Radioactive Material Area not identified with or within other appropriate radiological controls is posted with a sign meeting the applicable standards, including the trefoil radiation symbol and the words CAUTION RADIOACTIVE MATERIAL.

Exits from each Radioactive Materials Area do not require a personnel survey unless specified by the Radiation Protection Department; however, when a personnel survey is required, the area must be posted with STOP ALL PERSONNEL - SURVEY REQUIRED UPON EXITING, unless the area is contained within a larger 
area that has this sign posted at its exits.

\subsubsection{Underground Radioactive Material Areas}

An Underground Radioactive Material Area is an area established to indicate the presence of underground items that contain radioactive materials such as pipelines, radioactive cribs, covered ponds, covered ditches, catch tanks, inactive burial grounds, and the site of known, unplanned releases (spills).

Each Underground Radioactive Material Area is posted with a sign meeting the applicable standards, including the trefoil radiation symbol and the words UNDERGROUND RADIOACTIVE MATERIALS - CONSULT WITH RADIATION PROTECTION BEFORE DIGGING.

\subsubsection{Radiological Buffer Area}

A Radiological Buffer Area is an area established within the WVDP Controlled Area to provide secondary boundaries to minimize the spread of contamination and to limit doses to general employees who have not been trained as radiological workers.

Each Radiological Buffer Area is posted with a sign meeting the applicable standards, including the trefoil radiation symbol and the words CAUTION - RADIOLOGICAL BUFFER AREA.

Exits from each Radiological Buffer Area do not require a personnel survey unless specified by the Radiation Protection Department; however, when a personnel survey is required, the area must be posted with STOP ALL PERSONNEL - SURVEY REQUIRED UPON EXITING.

\subsection{Sealed Radioactive Source and Radloisotope Control}

No sealed radioactive sources may be purchased without the approval of Radiation Protection and an approved purchase specification. The control program for the purchase of radioisotopes (e.g., gas, liquid, or solid calibration standards, etc.) is essentially the same as that for sealed sources.

Upon receipt, sealed radioactive sources will be leak-tested and placed on the sealed radioactive source inventory list. Leaking sources will not be accepted and arrangements will be made for their safe return to the manufacturer. In addition to the receipt leak test, accountable sealed sources; as defined in DOE Notice 5400.9, "Sealed Radioactive Source Accountability," and the DOE Implementation Guide G-N 5400.9/M1, "Sealed Radioactive Source Accountability and Control;" are leak-tested semiannually. Radioactive source disposal is controlled as to disposition and requires removal from the radioactive source inventory list. The radioactive source inventory list also indicates transfer of radioactive sources between organizations. When not in actual use, accountable sealed radioactive sources are maintained in secured storage. Accountable sealed radioactive sources are inventoried semiannually.

Facilities that use high-radiation source range equipment or radiography equipment shall meet the requirements of DOE-mandated American National Standard ANSI N43.3, "General Radiation Safety for Installations Using Nonmedical X-Ray and Sealed Gamma-Ray Sources, Energies up to $10 \mathrm{MeV}$," and DOE/EH-0256T, as well as DOE Implementation Guide G-10 CFR 835/C3, "Radiation-Generating Devices." Records of site operations and of equipment maintenance and calibration are maintained in an auditable manner. 
The sealed radioactive source program meets the requirements of DOE Notice 5400.9 and DOE/EH-0256T, as well as DOE-mandated ANSI N43.3 and is implemented in WVDP-010 as well as radiological control procedures.

\subsection{Radlation Safety Training}

Radiation safety training is conducted at the WVDP to provide confidence that each worker understands: the general and specific radiological aspects of their assignment, their responsibility to co-workers and the public for safe handling of radioactive materials, and their responsibility for minimizing their own dose. As a general statement of policy, WVNS provides a level of training commensurate with an individual's work assignment and responsibilities. All radiation safety training meets the requirements contained in DOE documents such as 10 CFR 835, DOE/EH-0256T, and DOE/EH-0258T, "General Employee Radiological Training and Radiological Worker Training Program Management Manual," through DOE/EH-0262T, "Radiological Control Technician Training Program Management Manual," series standardized core training materials. The DOE Implementation Guide G-10 CFR 835/J1, "Radiation Safety Training," provides an acceptable methodology for establishing and operating a radiation safety training program. All WVDP radiation safety training requirements are set forth in WVDP-010.

In addition to completion of routine employee training programs, Radiological Control Technicians are required to demonstrate their proficiency in performing to a minimum standard in qualification examinations. The training standards for Radiological Control Technicians are maintained as separate qualification standards. Personnel who have not demonstrated acceptable performance to a documented standard for a given operation are not permitted to perform that operation except under the direct, continuous control of a qualified employee. Employees who have qualified but whose actions on the job may indicate a lack of knowledge in operational health physics are immediately disqualified and retrained.

The general process of radiation safety training is discussed in the following paragraphs:

\subsubsection{General Employee Radiological Training and Visitor Orientation}

All new employees are required to attend a General Employee Training (GET) Program. Even employees not directly involved in radioactive work are required to receive basic radiological training, which is repeated every two years, to provide confidence they understand the posting of radiologically controlled areas and the identification of radioactive materials. The instruction also explains the impact of the WVDP on the radiation environment of personnel employed outside radiation areas and outside the WVDP Facility. Additional instruction is provided on the recognition of emergency signals and the response of employees who have no formally designated responsibility during an emergency. Training for both general employees as well as onsite visitors complies with DOE/EH-0256T, DOE/EH-0258T, and DOE standardized core training requirements.

\subsubsection{Radiological Workers}

Before being authorized to work with radioactive materials (or to enter any radiologically controlled area unescorted), a worker is required to complete a formal course in radiological worker training and pass a written (or computer-based) and practical examination. Consideration of radiation exposure and contamination control are prominent in this training. The principal areas covered in training on radiation exposure control are:

- Limits for whole-body penetrating radiation and units of radiation dose 
- Use of "stay times"

- The seriousness of violations

- Procedures and methods for minimizing exposure, such as working at the maximum practicable distance from a source, limiting time in a radiation area, and the use of shielding

- Potential sources of radiation associated with work performed by an individual's trade

- Use of dosimetry equipment and personnel monitoring devices

- Posting and labelling

- Exposure records

- Biological risks of radiation exposures

- Procedures and methods for control of contamination

- Methods of personnel survey

- Use of protective clothing and "step-off" procedures.

In addition to classroom training, completion of the training course requires satisfactory performance during basic types of simulated work operations. This practical training is designed to cover situations that may be encountered in radiologically controlled areas of the Facility. Also incorporated into the training course are selected incident/accident reports that are discussed to familiarize the worker with how things can go wrong while on the job and lessons learned.

The radiological worker training program is divided into two areas: Radiological Worker I (RWI) and Radiological Worker II (RWII). RWI training focuses on radiation exposure control and RWI covers both radiation exposure control and contamination control. After the initial qualification training is complete, retraining is completed every two years. In the alternate years, refresher training is conducted to include changes in requirements and updates of lessons learned. Employees must follow the training information during all work activities. On-the-job training within each trade is also conducted in the specific job skills that may be performed in radiological areas. For complex jobs, this is followed by special training for specific operations, as required, using mock-ups outside radiological areas.

\subsubsection{Criticality Safety Training}

A criticality safety training program has been developed at the WVDP in accordance with the requirements of DOE Order 5480.20A, "Personnel Selection, Qualification, and Training Requirements at DOE Nuclear Facilities" and the DOE-mandated ANSI/ANS 8.20, "Nuclear Criticality Safety Training." Criticality safety training is given to individuals who operate, maintain, and/or supervise activities in areas where significant quantities of fissionable materials are stored or handled. Elements of the training program require that each individual receive instruction in nuclear criticality safety, including a summary of criticality accident history and nuclear criticality theory, normal procedures, radiation control practices, configuration control, criticality control zones, procedural compliance, and individual responsibility. Criticality safety training requirements are established in WVDP-162, "Nuclear Criticality Safety Program Manual." 


\subsubsection{Radiological Control Techniclans}

Radiological Control Technicians are required to complete an extensive course in radiological controls to demonstrate their practical abilities, and to pass comprehensive written, practical, and oral examinations in accordance with the requirements of $10 \mathrm{CFR} 835$ and DOE/EH-0256T. The first-line Radiological Control Operations Supervisor is required to have sufficient training to allow him or her to evaluate initial symptoms of unusual radiological control situations, state the immediate corrective action required, state what additional measurements are required, perform a final analysis of the measurements to identify the specific problem, and have the ability to implement the required actions. At least every 2 years, radiological control personnel requalify through written and oral examinations similar to those used for their initial qualification.

There are six levels of qualification for Radiological Control Technicians at the WVDP. The first three lower levels comprise the requirements under the DOE standardized core training program. The fourth through sixth levels of qualification go beyond the DOE Radiological Control Technician training program up through the National Registry of Radiation Protection Technology (NRRPT) certification at level six. If a Radiological Control Technician completes the next higher level of qualification within two years, retraining is not required. A continuing training program is provided for changes in requirements and updates of lessons learned.

\subsubsection{Dosimetry Technicians}

Dosimetry Technicians have a five-level qualification standard program. The qualification standards require a combination of experience and practical and theoretical knowledge. As the technicians progress in their qualifications they perform increasingly complex tasks.

\subsubsection{Resplratory Protectlon Tralning}

In addition to radiological worker training, all personnel who may be required to wear respiratory protection devices are required to attend a training program on their use during normal and emergency operations. They are fitted for the devices that are required to be worn and are given a special medical examination to provide confidence that they are capable of wearing the devices. Respiratory protection training complies with the requirements of DOE-mandated ANSI Z88.2 and Title 29, CFR, Part 1910, "Occupational Safety and Health Standards - General Industry," and Title 29, CFR, Part 1926, "Safety and Health Regulations for Construction." Requirements for the respiratory protection program are described in WVDP-179, "Respiratory Protection Program Plan."

\subsection{Personnel Monitoring Program}

Personnel at the WVDP are monitored for both internal and external dose. The monitoring equipment used is discussed in Section 6.4.

\subsubsection{Monitoring External Radiation Dose}

The external dosimetry monitoring program at the WVDP complies with requirements contained in 10 CFR 835, DOE Order 5480.15, and DOE/EH-0256T. The requirements are described in WVDP-010, "WVDP Radiological Controls Manual," and WVDP-071, "WVDP External Dosimetry Program Manual, Quality Assurance Plan, and Technical Basis Document," as well as radiological control procedures. A routine 
external dose monitoring program at the WVDP measures the radiation dose received by personnel. The basic monitoring device is the TLD.

Each dosimeter card contains four TLD phosphor elements. The four phosphor elements are contained within badge cases that provide various levels of shielding using various materials. Penetrating and non-penetrating radiation can be distinguished. Dosimetry badges are permanently issued only to those employees who have been trained to enter areas that require permanent dosimetry to be worn. These employees are called radiological workers.

The WVDP issues badges to four types of radiological workers: quarterly-badged RWIs, quarterly-badged RWIIs, monthly-badged RWIs, and monthly-badged RWIIs. These are determined by the employee's potential exposure. Those with a lesser potential are placed on a quarterly TLD-processing schedule. Employees with a greater potential for exposure are placed on a monthly TLD-processing schedule. In addition, workers on the monthly processing schedule are issued a self-reading pocket ionization chamber dosimeter to be worn in conjunction with the TLD badge.

Personnel dosimetry is issued only to radiological workers who meet the following criteria:

- Completed a whole-body count and/or bioassay baseline

- Included on the periodic whole-body count and/or bioassay roster

- Satisfactory completion of radiological worker training course (i.e., RWI or RWII)

- Completion of Facility indoctrination (i.e., GET)

- No precluding radiological restrictions

- A radiation dose history on file with or requested by Radiation Protection.

TLD badges may be issued to visitors who have a valid need to enter radiologically controlled areas requiring a permanent dosimeter. A visitor is defined as any WVDP employee who is not qualified as a radiological worker or any person not permanently assigned to the WVDP Facility who is not qualified as a radiological worker. Visitors are escorted in radiologically controlled areas by a qualified radiological worker at all times and are issued a visitor's dosimeter for a period not exceeding one week. A visitor's radiological exposure is not permitted to exceed $100 \mathrm{mRem}$ per year.

Persons not permanently assigned to the WVDP Facility may be qualified as radiological workers, in which case the visitor requirements are no longer applicable.

Radiological workers at the WVDP are monitored for external dose in accordance with DOE requirements contained in 10 CFR 835 and DOE/EH-0256T. The external dosimetry program is accredited by the DOELAP in accordance with DOE Order 5480.15. The DOELAP process requirements are defined in DOE/EH-0026 and DOE/EH-0027 and described in WVDP-071. The DOE Implementation Guide G-10 CFR 835/C2, "External Dosimetry Program," describes an acceptable methodology for establishing and operating an external dosimetry program. In cases where a limited portion of the body (e.g., head, arms) is exposed to the source of radiation, supplemental dosimeters are placed at the point of the highest anticipated dose rate to monitor the localized exposure.

The WVDP has also established requirements for evaluation and control of fetal exposure in accordance with 10 CFR 835 and DOE/EH-0256T. The DOE Implementation Guide G-10 CFR 835/C4, "Evaluation and 
Control of Fetal Exposure," provides an acceptable methodology for establishing and operating a fetal exposure control program. Requirements for the WVDP are described in WVDP-071.

\subsubsection{Internal Dose Assessment}

The internal dosimetry monitoring program at the WVDP complies with DOE requirements contained in 10 CFR 835 and DOE/EH-0256T. The DOE Implementation Guide G-10 CFR 835/C1, "Internal Dosimetry Program," provides an acceptable methodology for establishing and operating an internal dosimetry program. The internal dosimetry requirements for the WVDP are described in WVDP-010, "WVDP Radiological Controls Manual," and WVDP-070, "WVDP Internal Dosimetry Program Manual and Technical Basis Document," as well as radiological control procedures. Internal doses are assessed by personnel in vivo counting and in vitro radioanalysis techniques. The in vitro program is supported by a subcontract laboratory with provisions for routine, nonroutine, and emergency assessments of urine and/or fecal samples. The monitoring program is capable of detecting internal depositions of transuranic elements (plutonium), fission products (cesium and strontium), and activation products (tritium).

In vivo counters are used to measure the gamma rays from radionuclides present inside the body. This wholebody counter is sensitive to the relatively high-energy gamma rays emitted by fission products and, in general, can detect an internal deposition of gamma-emitting radionuclides at a level much less than 10 nanoCuries and less than one percent of the Annual Limit of Intake (ALI) as defined in 10 CFR 835.

In vitro bioassay analysis is used to monitor for strontium, tritium, uranium isotopes, and plutonium isotopes. Urinalysis is the normal method used in the bioassay program. Urine samples are collected to obtain the equivalent of a 24 -hour sample.

The routine internal exposure monitoring program is designed to detect deposition of both actinide and fission products. A majority of employees who are on the monthly TLD-processing schedule and those required to wear respiratory protection in radiologically controlled areas are required to submit a urine sample annually. All radiological workers permanently assigned to the WVDP are required to undergo a whole-body count annually. Radiological workers not permanently assigned to the WVDP are required to have whole-body counts at the start and termination of their work, and may also be required to submit urine samples initially and upon termination if the WVDP determines the need.

Additional internal dose assessment may be required if personnel are exposed during an accident in which radioactive contamination is released and:

- Detectable radioactivity is deposited in a person's nostrils or mouth or on the skin of the face

- The concentration of airborne radioactivity in an area is determined to exceed the derived air concentration (without respiratory protection)

- A worker has a potentially contaminated wound.

The extent of post-accident dose evaluations is determined in each case by the Radiation Protection Manager and may include urine sampling, fecal analysis, blood sample analysis, analysis of nose swipes, and lung or whole-body counting. 


\subsubsection{Dosimetry Records}

Dosimetry processing at the WVDP is performed by the Radiation Protection Dosimetry Office; however, the Lockheed-Martin Idaho Technologies Corporation (LITCO) Dosimetry and Records Department for the DOE Idaho Operations Office is the official records repository for WVDP dosimetry records. Requirements for external and internal dosimetry records are described in WVDP-071 and WVDP-070, respectively. These records include:

- Any pre-employment occupational exposure history

- External and internal exposure occupationally received, including that received at other installations, during employment at the WVDP

- Dose results from special dose evaluations

- Reports of unusual exposure (i.e., overexposure or incidents with the potential for internal deposition) and the results of any follow-up investigations.

Duplicate records are also maintained by the WVDP, but LITCO Dosimetry and Records is the legal repository for all WVDP dosimetry records.

A statement of exposure record is provided to employees:

- At least annually

- Ninety days following termination, when requested

- Upon request by the individual

- Upon submittal of an Occurrence Report, or report from a planned special exposure, to the DOE as a result of exceeding a DOE dose limit or Facility administrative control level.

In addition to the above records, the readings from ionization chambers are retained by Radiation Protection to allow the reconstruction or verification of exposures and for use in comparing pocket dosimeter/TLD data.

The dosimetry program record system is maintained in accordance with DOE requirements contained in 10 CFR 835 and DOE/EH-0256T.

\subsection{Airborne Radioactlvity Monitoring Program}

The function of the airborne radioactivity monitoring program is to comply with DOE requirements contained in 10 CFR 835 and DOE/EH-0256T, and to verify that the survey program described in Section 7.1 is detecting contamination control problem areas. The equipment used for air sampling and monitoring is described in Section 6.3. Requirements for the WVDP workplace airborne radioactivity monitoring program and the technical basis are presented in WVDP-216.

Fixed filters from the low-volume air samplers located throughout the Process Building are collected and analyzed weekly for gross alpha and gross beta activity. If the amount of radioactivity on the filter paper indicates that the work area DAC has been exceeded during the sampling period, the sample is tested to 
determine the isotopic content (tests may include alpha, beta, and/or gamma spectroscopy, and/or radiochemical analysis techniques). These data are used in performing follow-up assessments of internal dose.

Fixed filters on the CAM units are changed twice per week or more frequently if required by dust loading. These filters are analyzed with the same methods used for low-volume air sample filters.

High-volume air samplers are available for rapid measurement of airborne activity. The short-term samples are taken:

- If the installed CAM in a work area is inoperative and radioactive work is being performed

- When opening a radioactive system to the atmosphere for maintenance

- Before entering tanks or voids containing potentially radioactive piping

- Where a proposed operation could potentially release airborne radioactivity.

\subsection{Criticality Safety Program}

The Nuclear Criticality Safety Program is implemented by WVDP-162, "Nuclear Criticality Safety Program Manual," under the authority of the Radiation Protection Manager. The Program meets the requirements of DOE Order 5480.24, "Nuclear Criticality Safety," and the DOE-mandatory American Nuclear Society (ANS) standards required by the Order.

\subsubsection{Criticality Safety Control}

The Radiation Protection Department implements controls so that no nuclear criticality occurs following any two unlikely and independent credible events involving fissile materials. Factors affecting the potential for nuclear criticality will be considered in criticality safety analyses. These include:

- Mass of fissile material

- Source geometry

- Moderation

- Poisons

- Reflection.

Requirements for criticality analyses, verification, and internal review procedures, and documentation of analyses are presented in detail in the criticality safety requirements contained in WVDP-162 and are addressed in more specific detail in Facility-specific SARs.

In any area where criticality is credible, the Radiation Protection Department will provide for the inclusion of criticality safety requirements in all procedures, design documents, etc. in accordance with the requirements contained in WVDP-162. 


\subsubsection{Nuclear Criticality Safety Training}

Personnel receive Nuclear Criticality Safety training commensurate with their responsibilities as required by WVDP-162. The training program is briefly described in Section 7.5.

\subsubsection{Criticality Alarms and Dosimeters}

Criticality alarms and/or detection systems are placed if and when required by DOE Order 5480.24 . The criticality alarms and detection systems are designed to meet the requirements contained in DOE-mandated ANS 8.3-1986, "Criticality Accident Alarm System." Criticality dosimeters will be placed in and around areas containing criticality monitors and/or detection systems if and when required. Criticality dosimeters are thin metal tubes containing a variety of substances which, when activated, provide information on a criticality event.

\subsubsection{Abnormal Conditions}

In the event of an abnormal condition (i.e., one that may violate a mass or geometry control), no action will be taken except at the direction of the Radiation Protection Manager or designated representative. Following resolution of an abnormal condition, the corrective action taken and the preventive action to preclude recurrence of the event will be documented as specified in WVDP-162.

\subsection{Respiratory Protection}

At the WVDP, respiratory protection is required for both radiological and toxicological hazards. A comprehensive program, built around DOE-mandated ANSI Z88.2, and U.S. Occupational Safety and Health Administration (OSHA) standards, and in full compliance with applicable DOE requirements, is detailed in WVDP-179, "Respiratory Protection Program Plan." Further program requirements for radiological and toxicological hazard applications are set forth in WVDP-010, "WVDP Radiological Controls Manual," and WVDP-011, "WVDP Industrial Hygiene and Safety Manual," respectively. The WVDP Respiratory Protection Program comprises NIOSH-approved equipment, extensive employee training, quantitative fit testing, worker medical and bioassay monitoring, independent examination and maintenance of all reusable respirator components, and maintenance of records of all these activities. To provide for worker protection, all use of respiratory protection is strictly controlled by specification in either an RWP or Industrial Work Permit (IWP) as prepared by the Radiation Protection Department or Industrial Hygiene and Safety Department (IH\&S), respectively. Air-line respirators and full- and half-face air-purifying respirators are routinely used for worker protection while SCBAs are dedicated to emergency and unknown conditions. 


\subsection{REFERENCES}

\section{Federal Regulations}

Title 10, Code of Federal Regulation, Part 835, "Occupational Radiation Protection," December 1993, U.S. Department of Energy.

Title 29, Code of Federal Regulations, Part 1910, Occupational Safety and Health Standards - General Industry," U.S. Department of Labor.

Title 29, Code of Federal Regulations, Part 1926, "Safety and Health Regulations for Construction," U.S. Department of Labor.

Title 42, Code of Federal Regulations, Part 84, "Approval of Respiratory Protective Devices," U.S. Department of Labor.

\section{DOE Directives}

DOE Order 232.1, "Occurrence Reporting and Processing of Operations Information," September 1995, U.S. Department of Energy.

DOE Order 5400.5, "Radiation Protection of the Public and the Environment," January 1993, U.S. Department of Energy.

DOE Order 5480.1, Chapter XI, "Requirements for Radiation Protection," August 1981, U.S. Department of Energy.

DOE Order 5480.11, "Radiation Protection for Occupational Workers," December 1988, U.S. Department of Energy.

DOE Order 5480.15, "Department of Energy Laboratory Accreditation Program for Personnel Dosimetry," December 1987, U.S. Department of Energy.

DOE Order 5480.20A, "Personnel Selection, Qualification, and Training Requirements at DOE Nuclear Facilities," November 1994, U.S. Department of Energy.

DOE Order 5480.24, "Nuclear Criticality Safety," August 1992, U.S. Department of Energy.

DOE Order 5484.1, "Environmental Protection, Safety, and Health Protection Information Reporting Requirements," October 1990, U.S. Department of Energy.

DOE Notice 5400.9, "Sealed Radioactive Source Accountability," December 1991, U.S. Department of Energy (extended by DOE Notices 5400.10, 5400.12, and 5400.13).

\section{DOE Standards and Technical Manuals}

DOE/EH-0026, "Handbook for the Department of Energy Laboratory Accreditation Program for Personnel Dosimetry Systems," 1986, U.S. Department of Energy.

DOE/EH-0027, "Department of Energy Standard for the Testing of Personnel Dosimetry Systems," 1986, U.S. 
Department of Energy.

DOE/EH-0256T, "DOE Radiological Control Manual," April 1994, U.S. Department of Energy.

DOE/EH-0258T-1, "General Employee Radiological Training and Radiological Worker Training, "Program Management Manual," May 1995, U.S. Department of Energy.

DOE/EH-0258T-2, "General Employee Radiological Training and Radiological Worker Training, Training Aids," May 1995, U.S. Department of Energy.

DOE/EH-0259T-1, "General Employee Radiological Training, Lesson Plan," October 1992, U.S. Department of Energy.

DOE/EH-0259T-2, "General Employee Radiological Training, Study Guide," October 1992, U.S. Department of Energy.

DOE/EH-0261T-1, "Radiological Worker Training, Lesson Plans," May 1995, U.S. Department of Energy.

DOE/EH-0261 T-2, "Radiological Worker Training, Study Guides," May 1995, U.S. Department of Energy.

DOE/EH-0262T-1, "Radiological Control Technician, Training Program Management Manual," 1992, U.S. Department of Energy.

DOE/EH-0262T-2, "Radiological Control Technician, Standardized Technician Qualification Standard," 1992, U.S. Department of Energy.

DOE/EH-0262T-3, "Radiological Control Technician, Phase I, Core Academic Training Lesson Plans," 1992, U.S. Department of Energy.

DOE/EH-0262T-4, "Radiological Control Technician, Phase I, Core Academic Training Study Guides," 1992, U.S. Department of Energy.

DOE/EH-0262T-5, "Radiological Control Technician, Phase I, Site Academic Training Lesson Plans," 1992, U.S. Department of Energy.

DOE/EH-0262T-6, "Radiological Control Technician, Phase I, Site Academic Training Study Guides," 1992, U.S. Department of Energy.

DOE/EH-0262T-7, "Radiological Control Technician, Phase II, Core/Site Practical Training," 1992, U.S. Department of Energy.

DOE/EH-0262T-8, "Radiological Control Technician, Phase III, Oral Examination Boards," 1992, U.S. Department of Energy.

DOE/EH-0262T-9, "Radiological Control Technician, Phase IV, Facility Practical Training Attachment," 1992, U.S. Department of Energy.

DOE/EH-0262T-10, "Radiological Control Technician, Training Aids," 1992, U.S. Department of Energy.

DOE/PNL-6577, "Health Physics Manual of Good Practices for Reducing Exposure Levels that are As Low As Reasonably Achievable," 1988, Pacific Northwest Laboratory. 
DOE/EV/1830-T5, "A Guide for Reducing Radiation Exposure to As Low As Reasonably Achievable," 1980 , U.S. Department of Energy.

\section{DOE Implementation Guides}

DOE Implementation Guide G-10 CFR 835/B2, "Occupational ALARA Program," November 1994, U.S. Department of Energy.

DOE Implementation Guide G-10 CFR 835/C1, "Internal Dosimetry Program," November 1994, U.S. Department of Energy.

DOE Implementation Guide G-10 CFR 835/C2, "External Dosimetry Program," November 1994, U.S. Department of Energy.

DOE Implementation Guide G-10 CFR 835/C3, "Radiation-Generating Devices," November 1994, U.S. Department of Energy.

DOE Implementation Guide G-10 CFR 835/C4, "Evaluation and Control of Fetal Exposure," November 1994, U.S. Department of Energy.

DOE Implementation Guide G-10 CFR 835/E1, "Instrument Calibration for Portable Survey Instruments," November 1994, U.S. Department of Energy.

DOE Implementation Guide G-10 CFR 835/E2, "Workplace Air Monitoring," November 1994, U.S. Department of Energy.

DOE Implementation Guide G-10 CFR 835/G1, "Posting and Labeling for Radiological Control," November 1994, U.S. Department of Energy.

DOE Implementation Guide G-10 CFR 835/H1, "Occupational Radiation Protection Record-Keeping and Reporting," November 1994, U.S. Department of Energy.

DOE Implementation Guide G-10 CFR 835/J1, "Radiation Safety Training," November 1994, U.S. Department of Energy.

DOE Implementation Guide G-N 5400.9/M1, "Sealed Radioactive Source Accountability and Control," November 1994, U.S. Department of Energy.

\section{American National Standards}

ANSI/ANS 8.1-1983, "Nuclear Criticality Safety in Operations with Fissionable Materials Outside Reactors," American National Standards Institute and American Nuclear Society.

ANSI/ANS 8.3-1986, "Criticality Accident Alarm System," American National Standards Institute and American Nuclear Society.

ANSI/ANS 8.5-1986, "Use of Borosilicate-Glass Raschig Rings as a Neutron Absorber in Solutions of Fissile Material," American National Standards Institute and American Nuclear Society.

ANSI/ANS 8.7-1975, "Guide for Nuclear Criticality Safety in the Storage of Fissile Materials," American National Standards Institute and American Nuclear Society. 
ANSI/ANS 8.10-1983, "Administrative Practices for Nuclear Criticality Safety," American National Standards Institute and American Nuclear Society.

ANSI/ANS 8.15-1981, "Nuclear Criticality Control of Special Actinide Elements," American National Standards Institute and American Nuclear Society.

ANSI/ANS 8.20-1991, "Nuclear Criticality Safety Training," American National Standards Institute and American Nuclear Society.

ANSI N13.6-1966, "Practice for Occupational Radiation Exposure Record Systems, American National Standards Institute.

ANSI N43.3-1993, "General Radiation Safety - Installations Using Nonmedical X-Ray and Sealed GammaRay Sources, Energies up to $10 \mathrm{MeV}$," American National Standards Institute.

ANSI N323-1978, "Radiation Protection Instrumentation Test and Calibration," American National Standards Institute.

ANSI Z88.2-1992, "Respiratory Protection," American National Standards Institute.

\section{West Valley Demonstration Project}

WVNS Policy and Procedure WV-905, "Radiological Protection and Nuclear Criticality Safety," West Valley Nuclear Services Company, Inc.

WVNS Policy and Procedure WV-906, "Radiation and Safety Committee," West Valley Nuclear Services Company, Inc.

WVNS Policy and Procedure WV-984, "ALARA Program," West Valley Nuclear Services Company, Inc.

WVNS Project Document WVDP-010, "WVDP Radiological Controls Manual," West Valley Nuclear Services Company, Inc.

WVNS Project Document WVDP-011, "WVDP Industrial Hygiene and Safety Manual," West Valley Nuclear Services Company, Inc.

WVNS Project Document WVDP-070, "WVDP Internal Dosimetry Program Manual and Technical Basis Document," West Valley Nuclear Services Company, Inc.

WVNS Project Document WVDP-071, "WVDP External Dosimetry Program Manual, Quality Assurance Plan, and Technical Basis Document," West Valley Nuclear Services Company, Inc.

WVNS Service Manual WVDP-131, "WVDP Radiological Control Procedures," Volumes 1 through 5, West Valley Nuclear Services Company, Inc.

WVNS Project Document WVDP-162, "Nuclear Criticality Safety Program Manual," West Valley Nuclear Services Company, Inc.

WVNS Project Document WVDP-163, "WVDP ALARA Program Plan," West Valley Nuclear Services Company, Inc. 
WVNS Project Document WVDP-179, "Respiratory Protection Program Plan," West Valley Nuclear Services Company, Inc.

WVNS Project Document WVDP-216, "WVDP Workplace Radiological Air Sampling and Monitoring Program and Technical Basis Document," West Valley Nuclear Services Company, Inc.

WVNS Project Document WVDP-234, "WVDP Workplace Radiological Surface Measurements Program and Technical Basis Document," West Valley Nuclear Services Company, Inc. 
